\title{
AN APPRAISAL OF THE USEFULNESS OF LANDSAT5_TM IMAGERIES IN GROUNDWATER RECONNAISSANCE STUDIES IN ZARIA - KADUNA AREA, NORTH CENTRAL NIGERIA
}

A. E. BALA

(Received 19, January 2009; Revision Accepted 12, January 2010)

\section{ABSTRACT}

In order to assess the usefulness of remote sensing to groundwater resources studies especially with regard to the location of aquifers in the hard rock terrain, Landsat5_TM imageries were used in the Zaria - Kaduna area. In that area some information on the groundwater and the aquifers were already available.

Image interpretation was carried out in two parts. In the first part, a structural interpretation was done by marking lineaments (fractures), from which their density (length/$/ \mathrm{km}^{2}$ ) per cell of $2.5 \mathrm{~km} \times 2.5 \mathrm{~km}$ was calculated for the entire area. On the basis of the various values within the cells, a symbology of relative abundance of fractures in the area was created using classes to show the spatial distribution of areas where the fracture aquifer is likely to be encountered. The second part of the interpretation involved a spectral analysis and this was carried out employing the tasseled cap transformation. From the spectral analysis areas likely to produce good yields of water from the regolith aquifer were identified using interpretation keys.

From the analysis of the fracture density areas that are favourable for the accumulation of groundwater in fracture aquifer were identified. Similarly, the relative variation of depth to the water table inferred from the spectral analysis was used to deduce areas that are favourably disposed to yield groundwater from the regolith aquifer. The surface information obtained from both the structural and the spectral analyses can serve useful reconnaissance purposes.

KEY WORDS: Groundwater, basement rocks, Landsat5_TM, fracture aquifer, regolith aquifer, Nigeria

\section{INTRODUCTION}

Groundwater is randomly distributed in the regolith aquifer, and in fractures within the unweathered bedrock of the basement terrain. Although ground geophysical methods are employed for specific site investigations aimed at drilling productive boreholes on the terrain, they do not provide a regional or spatial information concerning the occurrence of the aquifers. Consequently, the level of field work to be carried out, or the depth to which a borehole is to drilled in a given locality cannot be predicted prior to going to the field. For this reason the cost of providing rural communities with borehole water is high as contract papers for such projects will usually specify depths to be drilled without regard to local hydrogeological situations.

Since satellite remote sensing has not been commonly applied to groundwater investigations, the results of this study were based on the summary of hydrogeological findings in earlier works which employed conventional methods of investigation. These were geological mapping based on aerial photo interpretation and selected ground traverses (Danladi, 1985), measuring depth to water table, and geological mapping and analysis of water samples (Alagbe, 1987), and using aerial photographs to produce a tectonic map and estimation of recharge using hydrometeorological data, (Adanu, 1989). All these workers analyzed geophysical and borehole data obtained from Messrs Preussag Drilling Engineers Limited to determine the nature and characteristics of the aquifers. Using the preexisting knowledge of the hydrogeology of the area of study the aim of this study was to assess the usefulness of remote sensing data obtained from Landsat_5 TM imageries in providing spatial information on the occurrence of groundwater in a region underlain by hard rocks. Consequently, interpretations were done in relation to, and limited to the results already available on the geology, tectonic information, depths to the water table, and the transmissivity of aquifer in the area.

\section{DESCRIPTION OFTHE STUDY AREA Location and Drainage}

The specific locations covered by the works are as follows; $11^{\circ} 14^{\prime} \mathrm{N}-11^{\circ} 23^{\prime} \mathrm{N}$ and longitudes $7^{\circ} 40^{\prime} \mathrm{E}$ - $7^{\circ} 55^{\prime} \mathrm{E}$, and latitudes $10^{\circ} 40^{\prime} \mathrm{N}-11^{\circ} 23^{\prime} \mathrm{N}$ and longitudes $7^{\circ} 30^{\prime} \mathrm{E}-7^{\circ} 47^{\prime} \mathrm{E}$ (Danladi, 1985); latitudes $10^{\circ} 38^{\prime} \mathrm{N}-10^{\circ} 52^{\prime} 43^{\prime \prime} \mathrm{N}$ and longitudes $7^{\circ} 11^{\prime} 23^{\prime \prime} \mathrm{E}$ $7^{\circ} 30^{\prime} 40^{\prime \prime}$ (Alagbe, 1987); and latitudes $10^{\circ} 30^{\prime} \mathrm{N}-11^{\circ}$ $00^{\prime} \mathrm{N}$ and longitudes $7^{\circ} 10^{\prime} \mathrm{E}-7^{\circ} 50 \mathrm{E}$ (Adanu, 1989) (Fig. 1).

The main rivers are the Karami and the Tubo which with their network of tributaries, drain into River Kaduna. Collectively, these rivers define a regional dendritic drainage pattern. The area falls upon an extensive, gently undulating peneplain. Around Zaria, the plain has an elevation which varies from about 800 $m-600 \mathrm{~m}$ above mean sea level, and has a regional southward slope. Principal terrain types are residual hills, inselberg areas developed by dissection of deep weathering profiles, and lowland landscape covered by laterite. 




\section{Geology and Hydrogeology}

The following account is based on the hydrogeological works named above. The general geology comprises migmatites and gneisses, metasediments and granites overlain by superficial deposits of laterite or alluvium (Fig. 2). However, outcrops of migmatites and gneisses are reported to be few. Granite gneisses form whalebacks and ridges and have gradational boundaries with the surrounding gneisses. Some varieties are banded.

The metasediments form continuous $\mathrm{N}$ - S outcrops. They consist of quartz/mica schists and quartzites. Schists form the bulk of the metasediments cropping out mainly in valleys. 


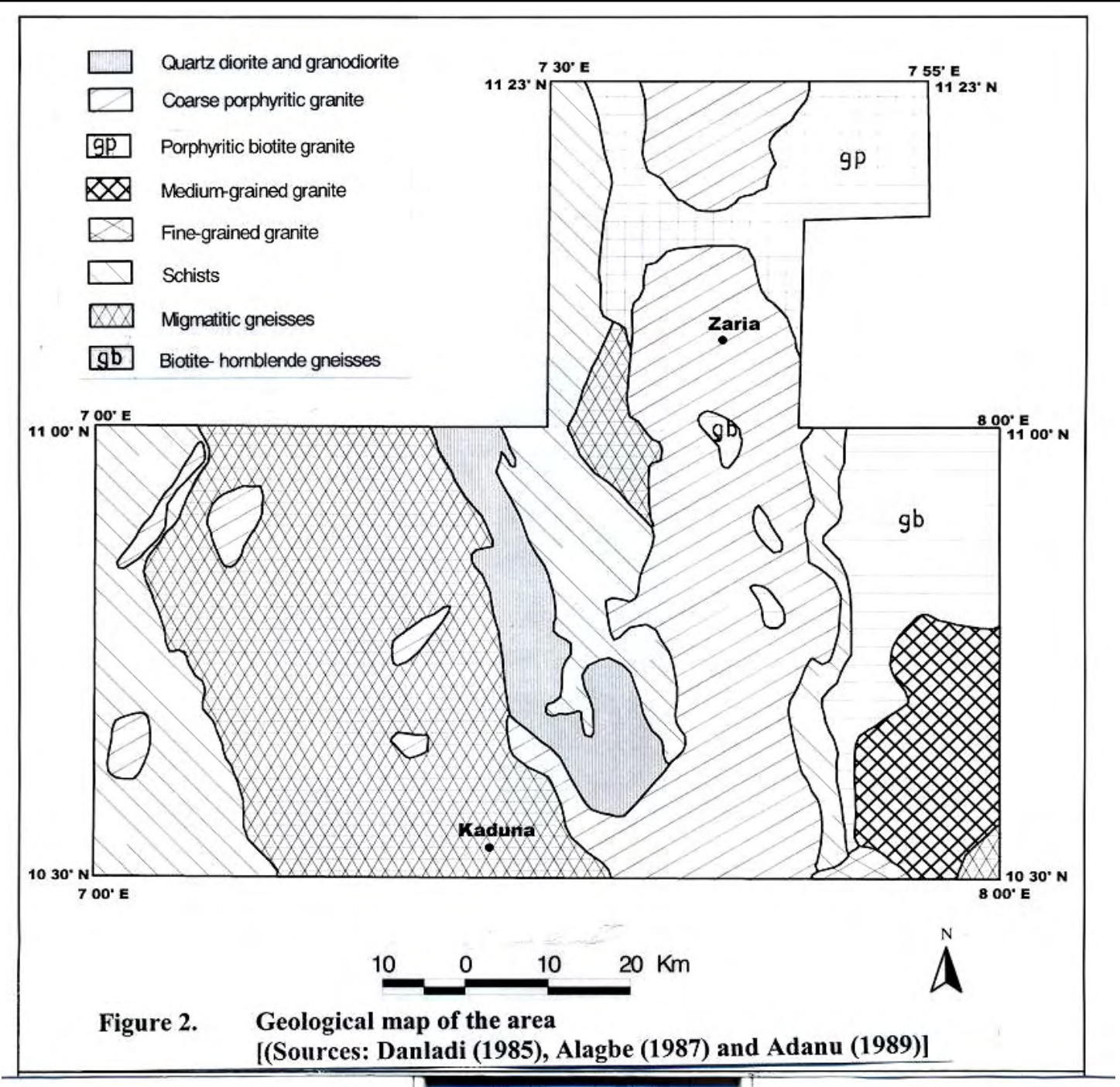

Granites form isolated hills and inselbergs cropping out as sub-elliptical plutons and batholiths. Two main types are found; medium- to coarse-grained, and the coarse porphyritic variety. Granodiorites are also found and form NNW - SSE elongate bodies which may appear as whalebacks or low-lying hills and platforms. Intrusive rocks of Proterozoic to Cambrian in age including orogenic to late orogenic granites, minor basic and ultrabasic rocks, dykes, pegmatites and aplite are also found (McCurry, 1973). Regional post orogenic joints and fractures displaying $\mathrm{N}-\mathrm{S}$ trends interpreted from aerial photographs are common. Overburden consists of extensive masses of saprolite which can be up to $50 \mathrm{~m}$ thick and may be overlain by laterite.

The summary of the hydrogeological findings according to the works, (Danladi, 1985, Alagbe, 1987 and Adanu, 1989) is as follows:

i) fresh crystalline rocks contain no water,

ii) two types of aquifers, the fractured rock and regolith aquifers are present,

iii) the specific yield of boreholes was observed to be similar in all rock types probably because the regolith aquifer of the different rocks possess similar hydraulic properties. The properties estimated from the analysis of pumping test data were found to be as follows;

- Specific capacity, $0.60 \mathrm{~m} 3 / \mathrm{m} / \mathrm{d}$ (minimum) and $33.70 \mathrm{~m}^{3} / \mathrm{m} / \mathrm{d}$ (maximum),

- Coefficient of permeability, $0.40 \mathrm{~m} / \mathrm{d}$ (minimum) and $3.60 \mathrm{~m} / \mathrm{d}$ (maximum),

- Ttransmissivity, $0.2 \mathrm{~m}^{2} / \mathrm{d}$ (minimum) and 27.0 $\mathrm{m}^{2} / \mathrm{d}$ (maximum).

iv) alluvial deposits along beds of river channels and along the banks of existing rivers contain water that depletes quickly as the dry season progresses, and

v) the regolith aquifer is unconfined except in some areas of metasediments.

The works reviewed here combined geological mapping applying aerial photo interpretation, geophysical survey results from resistivity method, and results of drilling on specific sites to determine areas of high and low potentials for groundwater occurrence. They concluded from the analysis of geophysical and pumping test data that areas with high transmissivity values were associated with fractures. These values of transmissivity were, in turn, used to deduce the localized 
nature of the fracture aquifer. The two aquifers in the area, that is, the regolith and the fractured rock aquifer are said to be in hydraulic connection (Adanu, 1989), (Fig. 3).

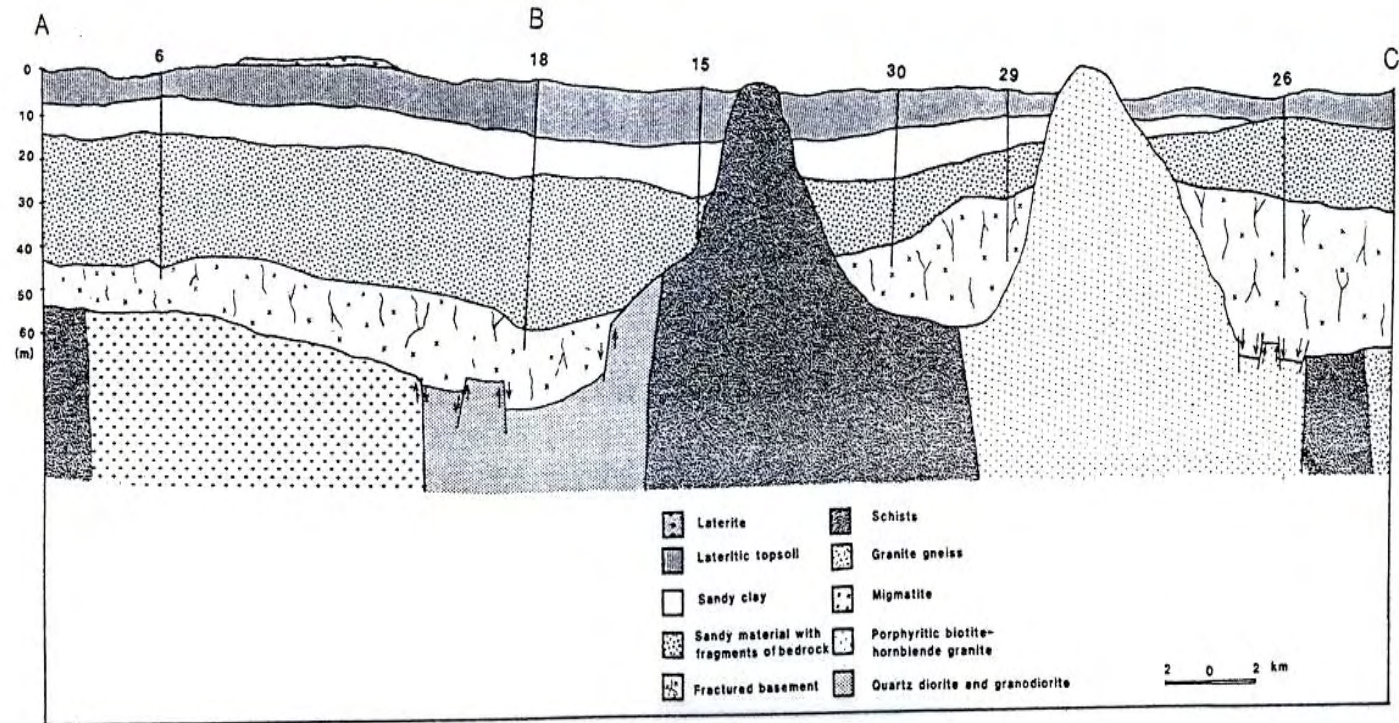

Figure 3. A hydrogeological cross-section for a part of the area. (ABC is a line of section and numbers show specific borehole locations and depthsAfter Adanu,(1989))

\section{MATERIALS AND METHODS OF PRESENT INVESTIGATION}

Landsat_5 TM imagery scenes numbers LT5189052008701110, LT5189053008701110 and LT5188053008702010 of January 1987 were used in this study. From these scenes the geographical area between Zaria and Kaduna corresponding to the Federal Surveys of Nigeria 1:100,000 (1965,1965, and 1965) topographical maps, Zaria Sheet 102, Kaduna Sheet 123 and Igabi Sheet 124, respectively, were clipped using Arc/Info 7.1.2. Image interpretation was carried out using ERDAS IMAGINE 8.3.1. All the image processing and map preparations were done on a computer running on WINDOWS NT Workstation 4 equipped with appropriate output devices.

Spectral interpretation involved enhancing the tasseled cap transformation equations of Crist et al.,
(1986) and interpreting the resulting image in RGB_312 in order to make the wetness axis the most important layer while making the greenness the least important. The enhancement was achieved by multiplying the set coefficients for both the brightness and greenness axes of the said equations by multipliers determined for each axis on the basis of the digital number of the relevant bands of the TM that were considered as outlined in Bala (2003). The mean digital numbers of the individual layers of the imagery sheets are presented in Table 1, and the multipliers determined from Table 1 for the Brightness axis (ratio of infrared bands to the visible bands), and Greenness axis (contrast between Band4 and Band 2 plus Band3, the vegetation-sensitive bands) of the tasseled cap transformation equations for the sheets are shown in Table 2. Then the sheets were mosaicked in RGB_312.

Table 1.Mean Digital Numbers of individual layers of imagery sheets in the Zaria - Kaduna area.

\begin{tabular}{|c|c|c|c|c|c|c|c|}
\hline \multirow[b]{2}{*}{$\begin{array}{l}\text { Sheet } \\
\text { No/Name }\end{array}$} & \multicolumn{7}{|c|}{ TM data layers. } \\
\hline & Layer1 & Layer2 & Layer3 & Layer4 & Layer5 & Layer6 & Layer7 \\
\hline $\begin{array}{l}\text { Sheet } 102 \\
\text { (Zaria) }\end{array}$ & 99.142 & 49.014 & 70.294 & 73.256 & 125.963 & 0.000 & 72.913 \\
\hline $\begin{array}{l}\text { Sheet } 123 \\
\text { (Kaduna) }\end{array}$ & 92.247 & 41.589 & 54.930 & 58.084 & 111.237 & 0.000 & 55.631 \\
\hline $\begin{array}{l}\text { Sheet } 124 \\
\text { (Igabi) }\end{array}$ & 93.953 & 43.658 & 59.514 & 62.456 & 121.118 & 0.000 & 61.326 \\
\hline
\end{tabular}


Table 2. Layer multipliers for Brightness and Greenness axes of the tasseled cap transformation equations for the imagery sheets for Zaria - Kaduna area.

\begin{tabular}{llll}
\hline Imagery sheet & Sheet 102 & Sheet 123 & Sheet 124 \\
\hline $\begin{array}{l}\text { Brightness } \\
\begin{array}{l}\text { axis } \\
\text { Greenness } \\
\text { axis }\end{array}\end{array}$ & 1.2457 & 1.1903 & 1.2424 \\
\hline
\end{tabular}

For the structural/tectonic analysis, the outcrops on each of the clipped "imagery sheets" were identified and marked, and the result was saved as an arc coverage. While disregarding these outcrops, fractures were identified and marked, and then saved as another arc coverage file. Using the attributes of each fracture which were automatically generated and stored in the Vector Cell Array in ERDAS while each fracture was being marked, the length of a fracture falling within a cell of a gridded mesh of $2.5 \mathrm{~km} \times 2.5 \mathrm{~km}$ in the sheet and hence the fracture density for the cell was determined. Then the interpretation of the structural/tectonic analysis was done using symbology as outlined in Bala (2001).

\section{RESULTS AND DISCUSSION}

Colour images of transformed spectral signatures were obtained from the spectral analysis (Fig. 4). The interpreted fractures in the area (Fig. 5) were converted to fracture density (Fig. 6) on which the higher the class the higher the prospects for locating fractures within the area represented by the cell.

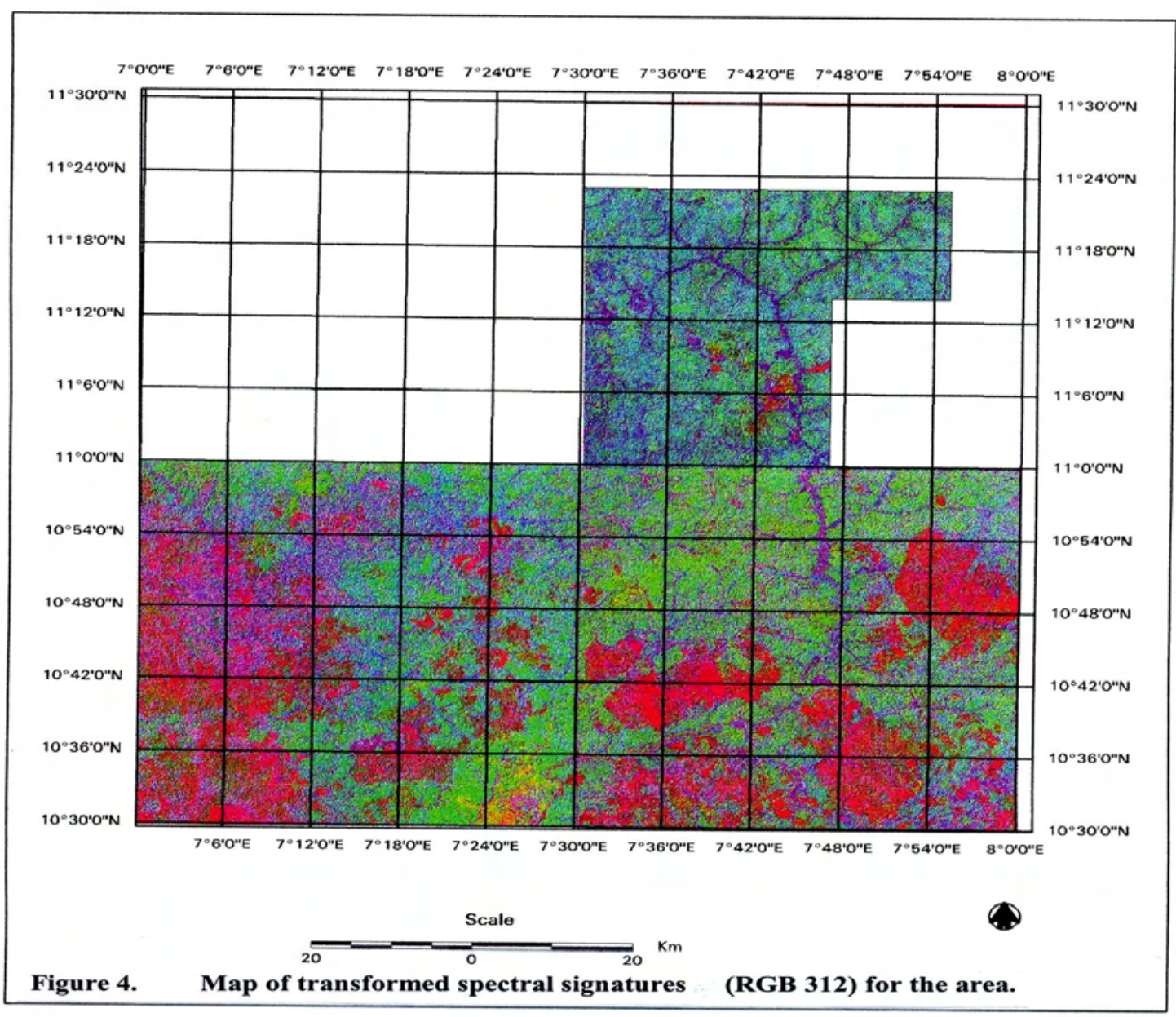




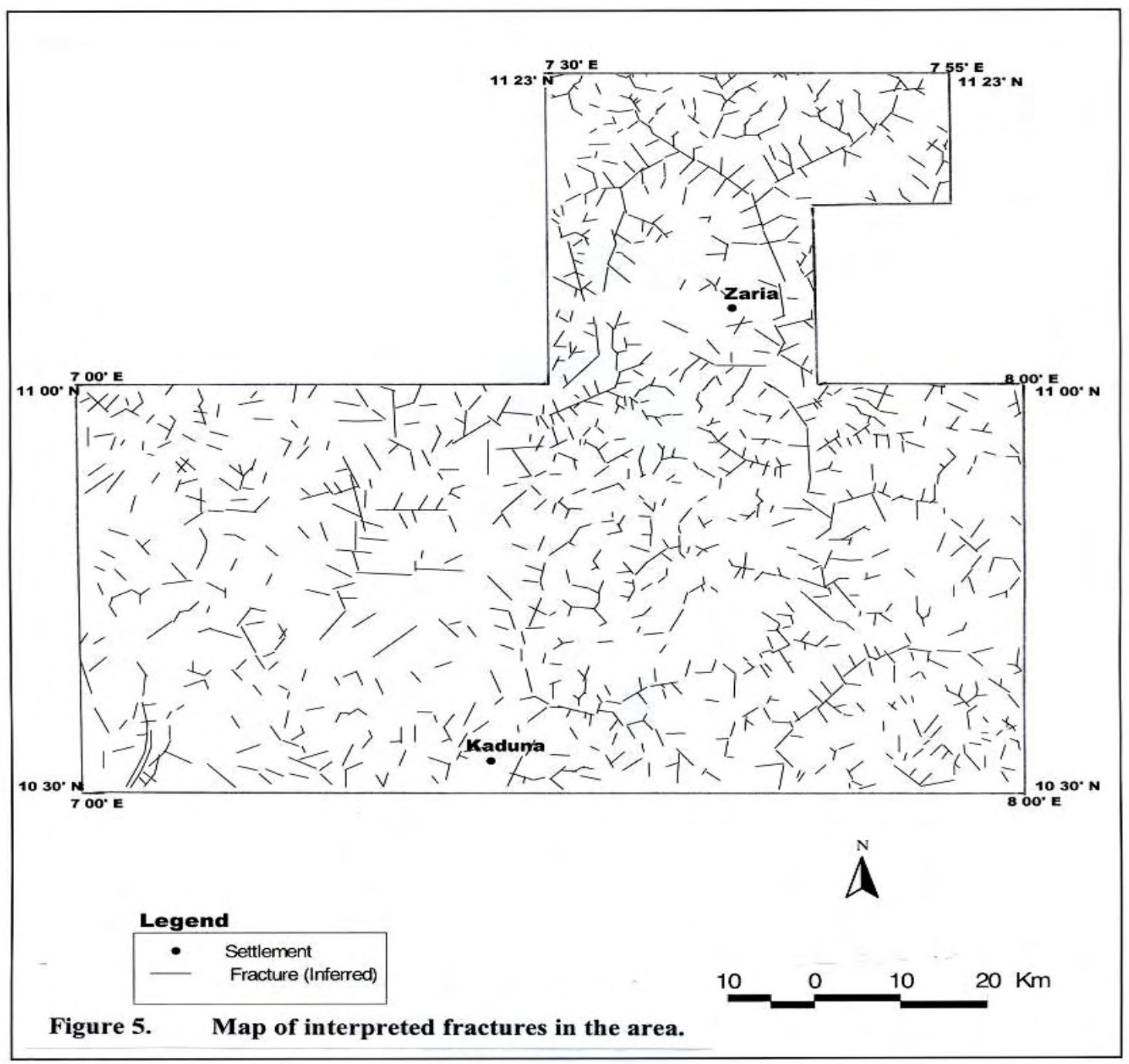

Figure 4 and Figure 6 represent generalizations about the distribution of groundwater in the area studied. Fig. 4 contains both non-economic groundwater areas represented by rock outcrops, and other areas representing regolith or alluvial aquifer. Measurements of depth to the water table in parts of the area were carried out. It was observed that areas showing magenta signature have water table at a depth of between $0 \mathrm{~m}$ and $3 \mathrm{~m}$ below surface; areas with purple signature have water table located between $3 \mathrm{~m}$ and 10 $\mathrm{m}$ below ground level, while green signature represents areas where water table lies beyond $10 \mathrm{~m}$ below ground level, and red signature represents open water bodies. Areas having water table at depths between. 


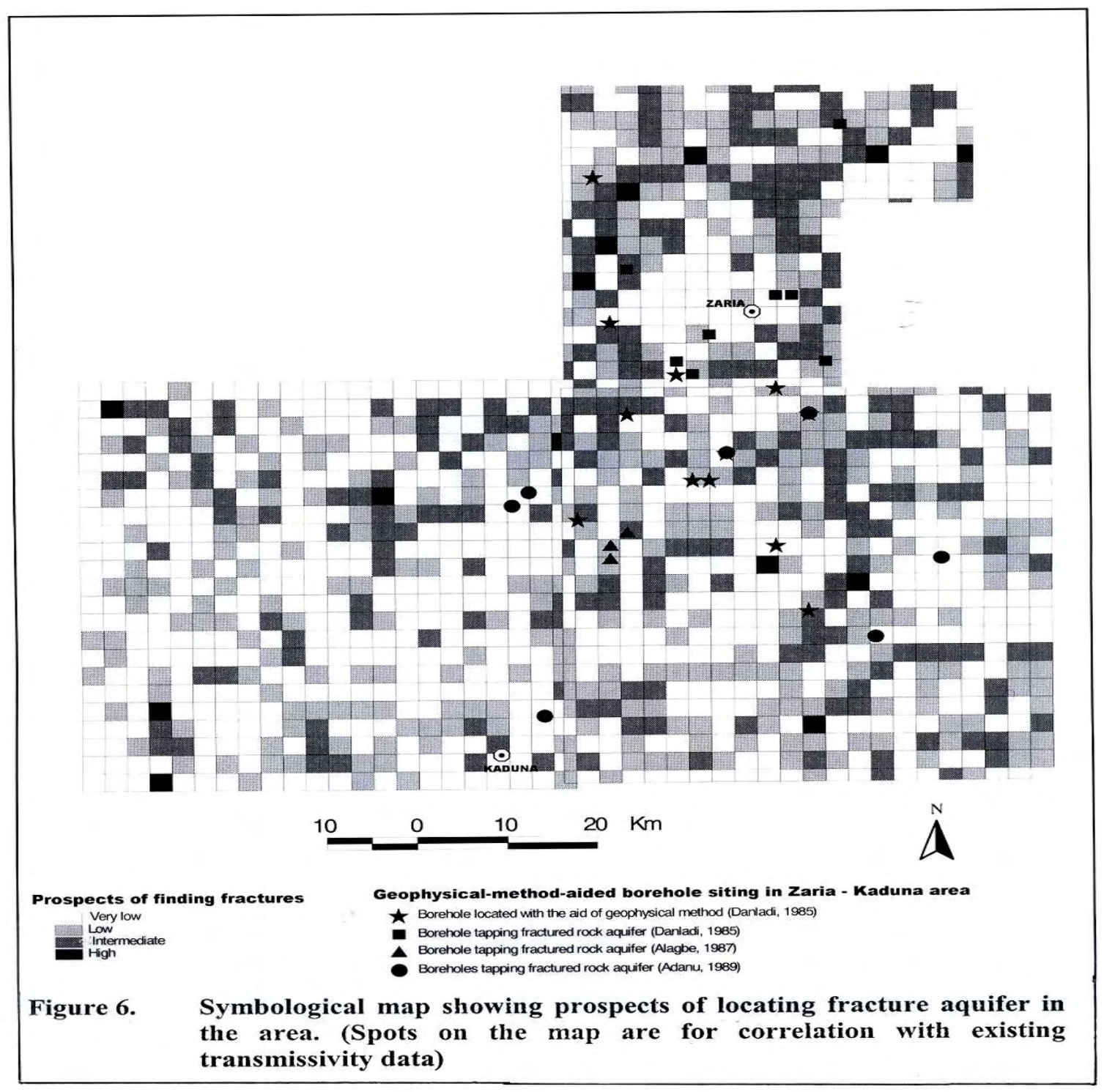

$0 \mathrm{~m}$ and $10 \mathrm{~m}$ below ground level are considered most favourable for groundwater abstraction from the regolith aquifer because in such areas aquifer yields tend to be higher than in those where water table is more deeply located (Bala, 2008).

Previous hydrogeological works cited above indicated that high transmissivity values are found with fractured rock aquifer. Transmissivity values considered in those works to be above the general average for aquifers on the basement (and which were said to be associated with fractures) and their locations within the studied area are listed in Table 3.

Source: Danladi (1985), Alagbe (1987) and Adanu (1989). 
Table 3. Locations of boreholes and their aquifer transmissivities reported the previous authors to be associated with fractures in the Zaria - Kaduna Area.

\begin{tabular}{llll}
\hline Author/Work & Location & $\begin{array}{l}\text { Lat./Long. } \\
\text { (Degree Decimal) }\end{array}$ & \\
\hline Danladi (1985) & Biye & $11.150 \mathrm{~N} / 7.567 \mathrm{E}$ & 18.3 \\
& Dogarawa & $11.117 \mathrm{~N} / 7.717 \mathrm{E}$ & 14.4 \\
& Hayin Tsugugi & $11.117 \mathrm{~N} / 7.733 \mathrm{E}$ & 27.0 \\
& Bogari & $11.067 \mathrm{~N} / 7.650 \mathrm{E}$ & 22.0 \\
& Aba & $11.033 \mathrm{~N} / 7.767 \mathrm{E}$ & 14.0 \\
& Hange & $11.033 \mathrm{~N} / 7.617 \mathrm{E}$ & 04.6 \\
& Mardanni & $11.017 \mathrm{~N} / 6.633 \mathrm{E}$ & 33.7 \\
& Gwibi & $11.333 \mathrm{~N} / 7.783 \mathrm{E}$ & 18.5 \\
\hline Alagbe (1987) & Kafin Musa Fate & $10.800 \mathrm{~N} / 7.550 \mathrm{E}$ & 55.2 \\
& Jaji & $10.817 \mathrm{~N} / 7.567 \mathrm{E}$ & 55.46 \\
& Birnin Yero & $10.783 \mathrm{~N} / 7.550 \mathrm{E}$ & 43.2 \\
\hline Adanu (1989) & Sabon Birni & $10.800 \mathrm{~N} / 7.300 \mathrm{E}$ & 18.1 \\
& Kurmin Kaduna & $10.583 \mathrm{~N} / 7.483 \mathrm{E}$ & 19.8 \\
& Dallatu & $10.867 \mathrm{~N} / 7.467 \mathrm{E}$ & 12.7 \\
& Zango Aya & $10.917 \mathrm{~N} / 7.667 \mathrm{E}$ & 52.3 \\
& Iruga & $10.967 \mathrm{~N} / 7.750 \mathrm{E}$ & 04.9 \\
& Rikoka & $10.683 \mathrm{~N} / 7.817 \mathrm{E}$ & 11.9 \\
& Birnin Yero & $10.783 \mathrm{~N} / 7.883 \mathrm{E}$ & 18.7 \\
& Juira & $10.850 \mathrm{~N} / 7.450 \mathrm{E}$ & 05.3 \\
\hline \hline
\end{tabular}

Total number of such boreholes is 19 while those sited on the basis of geophysical investigation was 13. The locations of these boreholes having good values of transmissivity were projected onto the symbological map of fracture density from ArcView GIS environment using information on latitudes and longitudes given on Table 3 and on Table 4 (Fig. 6). This map that is meant to show the relative chances of encountering fractures within the bedrock in an area depending on the class of the symbol indicate that for boreholes which are suspected to have intercepted fractures, 12 boreholes plot favourably on the symbological map of fracture density while the number is 9 for boreholes said to have been located with the aid of ground geophysical prospecting.

Table 4. Boreholes reported to have been sited after geophysical surveys and the aquifer transmissivities

\begin{tabular}{lll}
\hline Location & $\begin{array}{l}\text { Lat/Long. } \\
\text { (Degree Decimal) }\end{array}$ & Transmissivity $\left(\mathrm{m}^{2} / \mathrm{d}\right)$ \\
\hline Rafin Yashi & $11.083 \mathrm{~N} / 7.583 \mathrm{E}$ & 40.4 \\
Kundu & $11.083 \mathrm{~N} / 7.550 \mathrm{E}$ & 34.4 \\
Bajimi & $11.267 \mathrm{~N} / 7.533 \mathrm{E}$ & 38.8 \\
Sakadadi & $11.000 \mathrm{~N} / 7.717 \mathrm{E}$ & 03.9 \\
Ungwan Makera & $11.017 \mathrm{~N} / 7.617 \mathrm{E}$ & 94.9 \\
Jaji & $10.833 \mathrm{~N} / 7.517 \mathrm{E}$ & 62.0 \\
Dumbi & $10.967 \mathrm{~N} / 7.567 \mathrm{E}$ & 51.0 \\
Zango Aya & $10.917 \mathrm{~N} / 7.667 \mathrm{E}$ & 106.0 \\
Ashehu B. Kasuwa & $10.967 \mathrm{~N} / 7.750 \mathrm{E}$ & 88.0 \\
Tsohuwa Farakwai & $10.883 \mathrm{~N} / 7.650 \mathrm{E}$ & 26.0 \\
Farakwai & $10.883 \mathrm{~N} / 7.633 \mathrm{E}$ & 28.8 \\
Gadan Gaya & $10.717 \mathrm{~N} / 7.750 \mathrm{E}$ & 55.5 \\
Ung. Mal. Chindo & $10.800 \mathrm{~N} / 7.717 \mathrm{E}$ & 21.0 \\
\hline \hline
\end{tabular}


CONCLUSION

Through the analysis and interpretation of Landsat_5 TM imageries, regolith aquifer areas and river channel sections favourable to accumulation of groundwater were inferred for the Zaria - Kaduna area. Similarly, areas favourable for the presence of fractures and hence fractured rock aquifer were delineated. Since the aquifers of the basement in the area comprise the regolith and fractured crystalline rocks, a combined use of the map of spectral signatures and the symbological map of fracture density will indicate favourable groundwater areas for which management decisions towards exploitation may be taken accordingly. They can also be used to make a general regional assessment of groundwater potential of the area. Such maps can serve as an inexpensive means of obtaining reconnaissance groundwater information for a regional exploration programme especially as one problem highlighted by Alagbe et al. (2004) is that of method of hydrogeological investigation in this area. However, due to the coarse spatial resolution of the imageries, and the nature of the distribution of the ancillary data used in this investigation, the obtained results provide only general information on aquifers at those locations rather than information needed to site a borehole.

\section{ACKNOWLEDGEMENTS}

This research was partially funded with grants from Ahmadu Bello University. Technical support was provided by M. Mshelia, P. C. Njoku, Y. Usman, Isa Mainu, all of the National Agricultural Land Resources, Federal Ministry of Agriculture, Mando Road, Kaduna, Nigeria where the image processing and interpretation took place.

\section{REFERENCES}

Adanu, E. A., 1989. Hydrogeology of Basement Complex terrain in the Zaria - Kaduna area (Nigeria).Ph.D Thesis, TU, Berlin, 75p.

Alagbe, S. A., 1987. Hydrogeology of the River Kangimi catchment area, Kaduna State. Unpubl. M.Sc Thesis, Dept of Geology, Ahmadu Bello University, 168p.
Alagbe, S. A., Adanu, E. A. and Raji, B. A., 2004. Characteristics of the Basement Complex aquifers in Kaduna area in relation to rural water supply. Borno Journal of Geology, vol. 3 (4\&5): pp. $81-89$.

Bala, A. E., 2001. A symbological interpretation of fractures for the assessment of groundwater potential of Wudil and environs, northern Nigeria. WATER RESOURCES, Journal of the Nigerian Association of Hydrogeologists, 12, pp $27-31$.

Bala, A. E., 2003. An evaluation of Landsat_5 thematic mapper data as a tool for groundwater investigation in Basement Complex rocks of Nigeria. Unpubl. PhD Thesis, Dept of Geology, Ahmadu Bello University, 126p.

Bala, A. E., 2008. Optimum depth for boreholes in regolith aquifer of parts of northern Nigeria. Savanna, 21(2): pp. 77 - 89

Crist, E. P., Laurin, R. and Cicone, R. C., 1986. Vegetation and soils information contained in transformed thematic mapper data. Proceedings of IGARSS, ESA SP-254, pp.1465 -1470.

Danladi, G. G., 1985. Appraisal of hydrogeophysical investigations in shallow basement areas of Zaria, Kaduna State. Unpubl. MSc. Thesis, Dept. of Geology, Ahmadu Bello University, $114 p$.

Federal Surveys of Nigeria, 1965. Nigeria 1:100,000 Igabi Sheet 124.

Federal Surveys of Nigeria, 1965. Nigeria 1:100,000 Kaduna Sheet 123.

Federal Surveys of Nigeria,1965. Nigeria 1:100,000 Zaria Sheet 102.

McCurry, P., 1973. The geology of degree sheet 21, Zaria, Nigeria. Inst. of Geol. Sci. Overseas geol. and mineral resources, 45, $12 \mathrm{p}$. 